\title{
A Generalized Autoregressive Conditional Heteroskedasticity Model of the Impact of Macroeconomic Factors on Stock Returns: Empirical Evidence from the Nigerian Stock Market
}

\author{
Emeka Nkoro $^{1}$ \& Aham Kelvin Uko ${ }^{1}$ \\ ${ }^{1}$ Economics Department, University of Port Harcourt, Rivers State, Nigeria \\ Correspondence: Emeka Nkoro, Economics Department, University of Port Harcourt, Rivers State, Nigeria. E-mail: \\ nkoro23@yahoo.co.uk, ahamuko@yahoo.com
}

Received: June 8, 2013

Accepted: July 10, 2013

Online Published: October 8, 2013

doi:10.5430/ijfr.v4n4p38

URL: http://dx.doi.org/10.5430/ijfr.v4n4p38

\begin{abstract}
The study examines the impact of domestic macroeconomic variables on the Nigeria's stock market returns, using Generalized Autoregressive Conditional Heteroskedasticity (GARCH) model and annual data (1985-2009). We investigate the ability of these variables to predict the level of the stock market returns, using GARCH-M model. The results reveal that, out of the six macroeconomic variables employed, inflation, government expenditure, index of manufacturing output and, interest rate, exert strong significant influence on stock returns. Inflation and government expenditure have a positive significant impact, while index of manufacturing output and, interest rate have a negative significant impact. On the other hand, money supply and foreign exchange rate exert no significant influence on stock returns in Nigeria. The study observed that, there is volatility clustering in Nigerian stock market. Volatility of Nigeria's stock market returns was influenced by past volatility more than the economic news from the previous period. The time-varying volatility of the Nigeria's stock market returns is moderately persistent. In other words, a shock to the Nigeria's stock market volatility will last moderately long. Financial regulators, policy makers and investors need to take these macroeconomic variables into account when formulating economic and financial policies and, structuring of portfolio and diversification.
\end{abstract}

Keywords: macroeconomic factors, stock market returns, government expenditure, GARCH model

\section{Introduction}

Capital markets play an important role in the financial intermediation of any economy of the world. An efficient capital market can promote economic growth and prosperity by stabilizing the financial sector and providing an important investment channel that contributes to attract domestic and foreign capital. The stock market serves as a important tool in the mobilization and allocation of savings among competing uses which are critical to the growth and efficiency of the economy (Alile, 1984). The Capital market efficiency means the unanticipated portion of the return on a security is unpredictable, and over a sufficient number of observations, does not differ systematically from zero. The unanticipated portion is the actual return less what was expected based on some fundamental analysis (Buyuksalvarc1, 2010).

The relationship between macroeconomic variables and stock return is being continuously investigated by different scholars over the last few decades, among them are; Chen, Roll and Ross, 1986; Mukherjee and Naka, 1995; Mayasmi and Koh, 2000; Kown and Shin, 1999; Cheung and Ng, 1998; Gjerde and Saettem, 1999. This is done in order to identify the link between macroeconomic variables and stock return. The estimation of future trends of macroeconomic variables can be helpful in seeing the leading direction of stock returns. It is often believed that the stock return is determined by a number of fundamental macroeconomic variables such as interest rate, industrial production and inflation rate. And a good number of studies have captured the effects of macroeconomic variables on stock returns for different countries. Existing theories offer different models that make available framework for examining the relationship between stock return and macroeconomic variables (Quadir, 2012).

However, stock exchange in developing countries like Nigeria is generally characterized as unstable and shallow. These two features lead to the fact that macroeconomic dynamics still have the potential to play a very important role 
on stock market performance. The low volume of trade combined with unstable and shallow nature of Nigerian Stock Exchange (NSE) result in sensitivity of stock returns to macroeconomic development.

In modern portfolio theory, the most common approach of linking macroeconomic variables with stock return is through Arbitrage Pricing Theory (APT) developed by Ross (1976) where multiple risk factor can describe stock return. The APT was proposed as an alternative to Capital Asset Pricing Model (CAPM) developed by Sharpe (1964). The APT is similar to the CAPM in that it is also an equilibrium model. However, the APT is more general than the CAPM since it allows the equilibrium returns of assets to be dependent on many factors, not just one (Tunah, 2010). The APT assumes that the return on asset is a linear function of various macroeconomic factors or theoretical market indices, where sensitivity to changes in each factor is represented by a factor-specific beta coefficient.

Given the above background, the aim of this study is to examine the effects of macroeconomic variables on Stock market returns in Nigeria, using the APT framework. The findings of this study will enable investors to make optimal decision in their business investments. It is also expected that the findings of this study would provide meaningful insights to the body of literature, the views of policy makers as well as the practitioners. The rest of this study is structured as follows; Section 2 provides reviews of the related literature; Section 3 explains the data and methodology; Section four focuses on the empirical results and discussion and, section 5 presents the summary and conclusions.

\section{Literature Review}

Extensive empirical research has been undertaken to identify the impact of key macroeconomic variables on stock returns in developed, emerging and developing economies based on the Arbitrage Pricing Theory (APT). A brief review of the studies is presented in this section.

Chen, Roll and Ross (1986) were the first to study selected macroeconomic variables in relation to the US stock market returns using the APT model (multifactor model). That is, they studied the impact of macroeconomic forces on stock returns using APT. They examined seven macroeconomic variables, such as: term structure, industrial production, risk premium, inflation, market return, consumption and, oil prices. They revealed a strong relationship between the macroeconomic variables and the expected stock returns during the study period. They observed that industrial production, changes in risk premium, twists in the yield curve, measure of unanticipated inflation of changes in expected inflation during periods when these variables are highly volatile, are found significantly explaining expected stock returns (Burmeister and Wall, 1986, Clare and Thomas, 1994). Chen (1991) in a study on the USA stock market suggests that future market stock return could be forecasted by interpreting some macroeconomic variables such as default spread, term spread, one month t-bill rate, industrial production growth rate, and the dividend-price ratio. Replicating the Chen, Roll and Ross (1986), Hamao (1988) in his study of the Japanese stock market, using the multi-factor APT framework, revealed that the stock returns are significantly influenced by the changes in expected inflation and the unexpected changes in both the risk premium and the slope of the term structure of interest rates. In the same vein, Mukherjee and Naka (1995) used vector error correction approach to model to examine the relationship between Japanese stock return and macroeconomic variables. They found cointegration relation among stock prices and the six macroeconomic variables, namely exchange rate, inflation rate, money supply, real economic activity, long-term government bond rate and call money rate (Brown and Otsuki, 1990). Also, Diacogiannis (1986) and, Poon and Taylor (1991) replicated the Chen, Roll and Ross (1986) study on the United Kingdom market, contrarily, their results show that macroeconomic variables do not appear to affect share returns (Tursoy, Gunsel and Rjoub, 2008) in the United Kingdom as they do in the U.S. Hence, they were of the opinion that either different macroeconomic factor have an influence on share returns in the United Kingdom or the methodology employed by Chen, Roll and Ross (1986) is inefficient in detecting the relationship. However, Clare and Thomas (1994) were of different opinion, that a number of factors have been important in the UK stock market returns and are; oil prices, default risk and the retail price index, UK private sector bank lending, the current account balance and the redemption yield on an index of UK corporate debentures and loans. They revealed that oil prices, retail price index, bank lending and corporate default risk to be important risk factors for the U.K. stock returns. Furthermore, Priestley (1996) identified seven macroeconomic and financial factors, such as; default risk, industrial production exchange rate, retail sales, money supply, unexpected inflation, change in expected inflation, term structure of interest rate, commodity prices and market portfolio. He observed from the APT model that, with the factor generating from the rate of change approach, all factors are significant in the U.K stock market returns. The researchers' divergent views in U.K stock market analysis could be as a result of methodological issues order than macroeconomic factors introduced in the system. 
Maysami and Koh (2000) investigated the relationships between the Singapore stock index and selected macroeconomic variables over a seven-year period and they observed that there exists a positive relationship between stock returns and changes in money supply but negative relationships between stock returns with changes in price levels, short- and long-term interest rates and exchange rates. In the same vein, Wongbangpo and Sharma (2002) examine the relationship between stock markets and fundamental macroeconomic factors in the five South East Asian countries (Indonesia, Malaysia, Philippines, Singapore, and Thailand). Monthly data of GNP, the consumer price index, the money supply, the interest rate, and the exchange rate for the five countries were used. Their results showed that high inflation in Indonesia and Philippines influences the long-run negative relation between stock prices and the money supply, while the money growth in Malaysia, Singapore and, Thailand induces the positive effect for their stock markets. The exchange rate variable is positively related to stock prices in Indonesia, Malaysia, and Philippines, yet negatively related in Singapore and Thailand. Islam and Watanapalachaikul (2003) investigated the short-run dynamic adjustment and the long-run equilibrium relationships between four macroeconomic variables (interest rate, inflation rate, exchange rate, and the industrial productivity) and the Kuala Lumpur Stock Exchange (KLSE) Composite Index. In his study he concluded that, there was a significant short-run (dynamic) and long-run (equilibrium) relationships among the macroeconomic variables and the KLSE stock returns. Kandir (2008) examined the relationship macroeconomic factors and stock returns in Turkish. Macroeconomic variables used were growth rate of industrial production index, change in consumer price index, growth rate of narrowly defined money supply, change in exchange rate, interest rate, growth rate of international crude oil price and return on the MSCI World Equity Index and the analysis is based on stock portfolios rather than single stocks. He observed that exchange rate, interest rate and world market return seem to affect all of the portfolio returns, while inflation rate was significant for only three of the twelve portfolios. On the other hand, industrial production, money supply and oil prices had no significant effect on stock returns. Gazi and Hisham (2010) examined the relationship between macroeconomic variables and stock market returns in the Jordan Stock Market, using cointegration analysis, and affirmed that the trade surplus, foreign exchange reserves, the money supply and oil prices are important macroeconomic variables have long run effects on the Jordanian stock market returns. Also, that a negative relationship exists between crude oil price and stock market returns. This is also expected as increase in the price of oil will depress real economic activity, so a negative sign is justified and that interest rate does not affect the stock market returns. Also, Robert (2008) examined the effect of macroeconomic variables on stock market returns for four emerging economies of Brazil, Russia, India and China, contrarily, he concluded that, there was no significant relationship between present and past market returns with macroeconomic variables, suggesting that the markets of Brazil, Russia, India and China exhibit weak form of market efficiency (Poon and Taylor, 1991). Also, no significant relationship was found between respective exchange rate and oil price on the stock market index prices of the four countries studied.

Anokye and Tweneboah (2008) analyze the role of macroeconomic variables on stock returns in Ghana. They used the Databank stock index to proxy Ghana Stock market and the macroeconomic variables used are; inward foreign direct investment, Treasury bill rate (as a measure of interest rate), consumer price index (as a measure of inflation) and exchange rate. They examined both long-run and short-run relationships between the stock market index and the economic variables with quarterly data. They found that there is cointegration between macroeconomic variables identified and stock prices in Ghana, indicating long run relationship. Result of impulse Response Function (IRF) and Forecast Error Variance decomposition (FEVD) indicate that interest rate and foreign Direct Investment (FDI) are the key determinants of the share price movements in Ghana. Soyode (1993) examined the relationship between stock prices and macroeconomic variables such as exchange rate, inflation and interest rate in Nigeria. He discovered that the macro economic variables are cointegrated with stock prices and consequently related to stock returns. Kyereboah and Agyire (2008) investigated how macroeconomic indicators affect the performance of Ghana stock market using quarterly time series data. They observed that lending rates from deposit money banks have an adverse effect on stock market performance and particularly serve as major hindrance to business growth in Ghana. Inflation rate was found to have a negative effect on stock market performance. Asaolu and Ogunmuyiwa (2011) examined the impact of long-run and short-run macroeconomic variables on stock prices, using cointegration and error correction model. Their result shows that a long run relationship exists between Average Share Price (ASP) and the macroeconomic variables, however the Granger causality results failed to confirm any relationship between ASP and macroeconomic variables in Nigeria (Gan et al, 2006). Only exchange rate was found to Granger cause ASP in the sample period. This reveals that ASP is not a leading indicator of macroeconomic variables in Nigeria and that movements in stock prices can not actually be explained by macroeconomic factors. Contrarily, Maku and Atanda (2009) examined the long-run and short-run macroeconomic shocks effect on the Nigerian capital market between 1984 and 2007 using cointegration and error correction model. Their result showed that the All Share Index (ASI) is 
more responsive to changes in exchange rate, inflation rate, money supply and real output. Therefore, all the variables in the system that serve as proxies for external shock and other macroeconomic indicators have joint significant impact on the Nigerian capital market returns, both in the short and long-run. In the same line, Amadi, Oneyema and Odubo (2000) estimated the relationship between money supply, inflation, interest rate, exchange rate and stock prices using multiple regression in Nigeria. Their result revealed that the relationship between stock prices and the macroeconomic variables are consistent with theoretical postulation and empirical findings of other scholars. However, they observed that the relationship between stock prices and inflation does not agree with some other works done outside Nigeria.

Given the above review, in this line of thought, there is no doubt that the impact of macroeconomic variables on stock returns produced mixed results. Different methods have been employed to test the relationships between macroeconomic variables and stock returns in various economies. In doing this, there was no standardized set of macroeconomic variables adopted. Macroeconomic variables selected in order to determine stock market returns slightly differ across studies. However, inflation rate, exchange rate, interest rate, industrial production index and money supply are the most commonly used factors in explaining the stock market movement. In order to further explore this in Nigeria, this study also considers government expenditure and among other macroeconomic factors.

This study is different from the previous studies undertaken in Nigeria, by taking into account, the time varying effect of the financial variables which were ignored by the previous studies. Since the relationship between stock returns and macroeconomic variables changes significantly over time, therefore, it has become expedient to further explore this in Nigeria situation.

\section{Data and Methodology}

\subsection{Data Source}

The time series data for study were sourced from Central Bank of Nigeria (CBN) Statistical Bulletin, Federal Office of Statistics (FOS) Statistics and Nigeria Stock Exchange Quarterly and Statistics of various issues were used. The macroeconomic data used include; Nigeria Stock Market Returns(NMSR), Inflation Rate (INFR), Government expenditure(GEXP),Foreign Exchange Rate (FEXR), Index of Manufacturing Output (IMO), Broad money supply(BMS), and Minimum Rediscount Rate (MRR) between 1985 and 2007. This period was adopted because of the availability of data on All Share Price index before 1985. The All Share Price Index was first publicly published in the Nigerian Stock Market in 1985, with 1984 value as a base year. The All Share Index (ASI) represents the dependent variable while the other variables are the exogenous variables.

\subsection{Data Description and Model Specification}

This section provides a simple description of the variables used in the model and also specifies the model used in the empirical investigation of the relationship between stock returns and macroeconomic variables.

\subsubsection{Stock Market Returns (SMR)}

Nigerian stock exchange market All Share Index was used as a proxy for stock market returns (SMR). The All share index (ASI) is a broad market indicator of the stock market, which measures the overall performance of the stock market and was specified as the dependent variable.

Stock returns, $S M R$, are obtained as: $D L N S M R_{t}=\left(S M R_{t} / S M R_{t-1}\right)$, where DLNSMR is first difference of log stock market returns, $S M R_{t}$ is the annual value of Nigeria's All Share index.

\subsubsection{Inflation Rate (INFR)}

Inflation is being captured be consumer price index. Rising inflation increases the cost of living and shifts resources from investments to consumption. This brings about a fall in demand for market instruments, which in return leads to reduction in the volume of stock traded. Also the monetary policy responds to the increase in the rate of inflation with economic tightening policies, which in turn increases the nominal risk - free rate and hence, raises the discount rate which results in reduction of present value of cash flows so it is said that an increase in inflation is negatively related to stock prices. Chen, Roll and Ross (1986), Barrows and Naka (1994), Mukherjee and Naka (1995) and Wongbangpo and Sharma (2002) conclude that inflation has negative effects on the stock market. Conclusively, there is a negative relationship between inflation rate and stock prices/returns.

Inflation Rate (INFR), is obtained as: $D L N I N F R_{t}=\left(I N F R_{t} / I N F R_{t-1}\right)$, where DLNINFR is first difference of log Inflation rate, $I N F R_{t}$ is the annual value of Nigeria's inflation rate. 


\subsubsection{Foreign Exchange Rate (FEXR)}

Exchange is the price of a unit of a given currency in relation to other currencies. The performance and profitability of industries and companies that are major importers or heavy users of imports are considerably affected by the exchange rate of one country's currency against major currencies of the world (Osamwonyi 2003). For an import dominated country; currency depreciation will have an unfavorable impact on a domestic stock market. As the nation's currency depreciates against a major currency, products imported become more expensive. Hence, if the demand for these goods is elastic, the volume of imports would increase, which in turn causes lower cash flows, profits and, the stock price of the domestic companies. Ajayi and Mougoue (1996), Bilson et al., (2001) Ibrahim and Aziz (2003) found a negative sign and that a devaluation of the domestic currency has a negative relationship with returns. Contrarily, Geske and Roll (1983) and, Malliaropulos (1988) found a positive sign and, that a devaluation of the domestic currency is expected to increase stock price through competition.

Foreign Exchange Rate, FEXR, are obtained as: $D L N F E X R_{t}=\left(F E X R_{t} / F E X R_{t-1}\right)$, where DLNFEXR is first difference of log foreign exchange rate, $\mathrm{FEXR}_{\mathrm{t}}$ is the Nigeria's naira value to US dollar for a year.

\subsubsection{Index of Manufacturing Output (IMO)}

Index of Manufacturing Output is used as proxy to measure the growth rate in the real sector. Index of Manufacturing Output is used as a measure of domestic macroeconomic activity in the economy and it affects stock prices through its influence on expected future cash flows. Increased production leads to higher revenues and profits, together with high volume of cash flow, which in turn leads to increase in stock returns. Fama (1981), Chen, Roll and Ross (1986), Kaul (1987), Lee (1992), Mukherjee and Naka (1995), Ibrahim and Aziz (2003) found a positive sign. Thus, it is expected that an increase in Index of Manufacturing Output is positively related to stock returns.

Index of Manufacturing Output, IMO, is obtained as: $D L N I M O_{t}=\left(I M O_{t} / I M O_{t-1}\right)$, where $D L N I M O$ is first difference of $\log$ index of manufacturing output, $\mathrm{IMO}_{\mathrm{t}}$ is the annual value of Nigeria's index of manufacturing.

\subsubsection{Broad Money Supply (BMS)}

Broad Money Supply is used as a proxy of money supply. Increase in money supply leads to increase in liquidity that ultimately results in upward movement of nominal stock prices. Mukherjee and Naka (1995) and, Maysami and Koh (2000) found a positive sign. Contrarily, Udegbunam and Oaikhenan (2002) observed that there are consensus of views in this regard, that monetary growth, except accompanied by growth in output of goods and services, leads to inflationary spiral on the economy, hence, as investors diversify their portfolio holdings away from financial assets to real assets, this in turn drives stock prices downwards. This measure is often adopted by investors to hedge against the erosive effect of inflation on financial assets. Chancharat, Valadkhani, and Havie (2007), in their study, "impact of macroeconomic factors on stock returns in Thailand", found that money supply have no impact on stock returns. Also, Pearce and Roley (1983) and, Serletis (1993) investigated the relationship between stock returns and money growth and found that monetary variables and stock returns do not cointegrate. This has led to mixed results.

Broad money supply, BMS, is obtained as: $D L N B M S_{t}=\left(B M S_{t} / B M S_{t-1}\right)$, where $D L N B M S$ is first difference of $\log$ broad money supply, $B M S_{t}$ is the annual value of Nigeria's broad money supply.

\subsubsection{Minimum Rediscount Rate (MRR)}

There are many literature on the relationship between interest rates and stock returns. The results presented are mixed. Hashemzadeh and Taylor (1988) found that an increase in interest rate motivates a potential investor to change the structure of the portfolio in favour of bond. Shiller and Beltratti (1992) favour a positive relationship by arguing that change in interest rates could carry information about certain changes in future fundamentals such as dividend. Barsky (1989) explains the positive relationship between interest rates and stock prices in terms of a change in the risk premium. In contrast, Chen, Roll and Ross (1986), Beenstock and Chan (1988), Fifield et al. (2002) and, Chandra (2004) provide evidence on the relationship between interest rates and stock returns. High interest rate regimes lead to high cost of borrowing and hence a reduction in economic activity. This also affects corporate profit, future cash flow of business and dividend. They submit that a rise in interest rate depresses corporate profitability and also leads to an increase in the discount rate applied to equity investors; both of which have adverse impact on stock prices, and vice-visa. They concluded that interest rates are expected to be negatively related to market returns either through the inflationary or discount factor effect. The Minimum rediscount rate was used.

Minimum Rediscount Rate, MRR, are obtained as: $D L N M R R_{t}=\left(M R R_{t} / M R R_{t-1}\right)$, where $D L N M R R$ is first difference of $\log$ minimum rediscount rate, $M R R_{t}$ is the annual value of Nigeria's interest rate. 


\subsubsection{Government Expenditure (GEXP)}

Government's expenditure plays an important role in most economies. Government expenditure on productive sector stimulates economic activity in the economy and also affects stock prices through its influence on expected future cash flows. Government expenditure is positively related to stock returns. The increasing government expenditure through fiscal deficits leads to rise in the level of money supply in the economy and, this generally affects all prices in the economy, stock prices not excluded.

Government Expenditure, GEXP, is obtained as: $D L N G E X P_{t}=\left(G E X P_{t} / G E X P_{t-1}\right)$, where DLNGEXP is first difference of $\log$ government expenditure, $G E X P_{t}$ is the annual value of Nigeria's government total expenditure.

\subsection{Descriptive Statistics}

Before the regression analysis was carried out, the stationarity of the variables were checked using the Augmented Dickey Fuller test and, also the descriptive analysis of the stock returns (LogSMR) was carried out to check the features of the stock returns, such as volatility clustering, leptokurtosis, and the assumption of hetroscedasticity. These characteristics of $S M I_{t}$ are essential for the Generalized Autoregressive Conditional Heteroskedasticity (GARCH) modeling. The results show that LogEXRATE, LogGEXP, and LogMRR were stationary at levels while $\log S M R, \log I N F R, \log I M O$ and $\log B M S$ were stationary after first differencing. Subsequently, a cointegration test was also carried out to examine the long run relationship of the Nigeria's stock returns and Macroeconomic variables. The results showed that, there is a long run relationship between Nigeria's stock returns and Macroeconomic variables. These are not displayed here, but can be provided on demand. Hence, we moved to specifically examine other statistical properties of Nigeria's All Share Index(SMI) that are essential for fitting the Generalized Autoregressive Conditional Heteroskedasticity (GARCH) of models, as mentioned above. Table 1 below contains basic descriptive statistics for annual stock returns of the Nigeria's stock market. As can be observed from table below, the sample mean of the Nigeria's stock market return is 11175.46.

Table 1. Descriptive statistics for Nigeria's stock market returns

\begin{tabular}{lllllllll}
\hline Mean & Max & Min & Std. Dev & Skewness & Kurtosis & Jarque-Bera & P-Value & Obj \\
\hline 11175.46 & 57990.20 & 127.3000 & 14198.02 & 1.709202 & 5.770217 & 20.16624 & 0.000042 & 25
\end{tabular}

Note: The standard value for normal distribution is equal to 3 , the normal distribution skewness value is equal to zero. Jarque-Bera is used to test the hypothesis of normality.

Source: Author's calculation

The unconditional standard deviation of 14198.02 shows that Nigeria's stock market returns were volatile during the sample period. The kurtosis coefficient of 5.770217 implies that this series strongly departs from normality, since it exceeds 3 which is normal value. This shows that the stock market returns is tailed to right. This reveals that the market stock returns exhibit leptokurtosis.As expected, the Jarque-Bera normality test strongly rejects the null hypothesis of normality for Nigeria stock market returns. Also, the series exhibit asymmetric skewness. It skewed to right (1.7), which shows that investors in Nigeria's stock market are likely to earn positive returns.

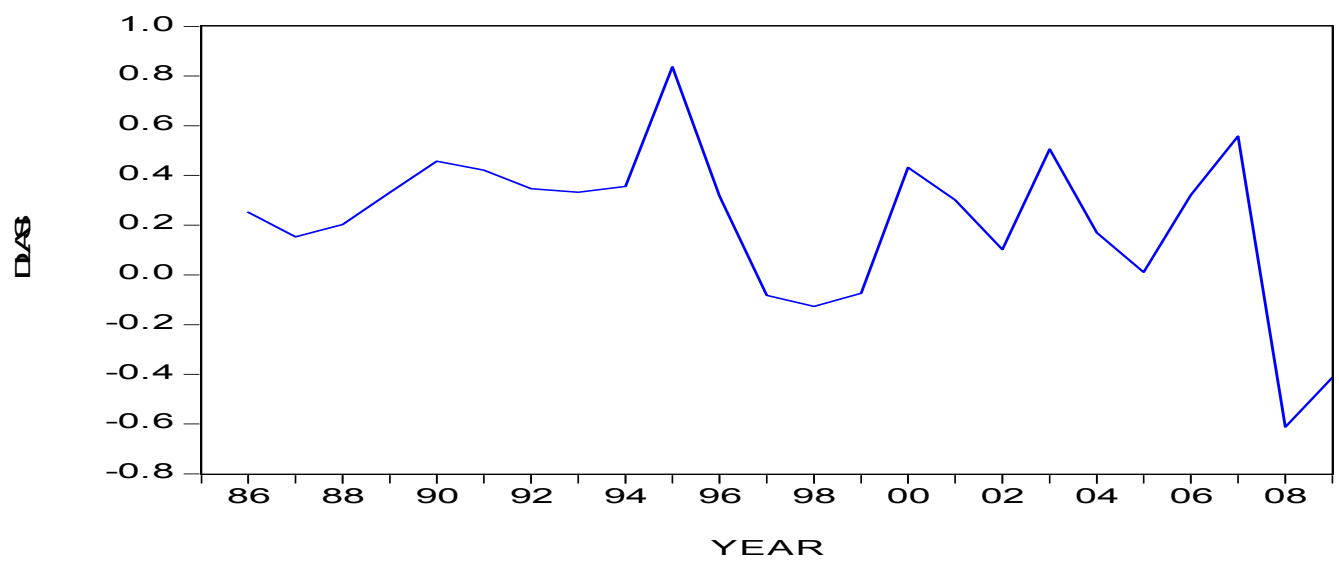

Figure 1. Nigeria's stock market returns 
Another feature of stock market returns is volatility clustering. It is clearly seen from Figure 1 above, that periods of high (low) volatility in Nigeria's stock market returns are followed by periods of high (low) volatility. Theoretically, clustered volatility reveals that at the beginning of each period new information leads to higher volatility associated with large returns. This can be attributed to the phenomenon of heterogeneity of expectations (Kirchler and Huber, 2007).

Table 2. Ljung-box Q-statistics for Nigeria's stock market returns

\begin{tabular}{rrrrl}
\hline LAG & AC & PAC & Q-Stat & Prob \\
\hline 1 & 0.810 & 0.810 & 18.448 & 0.000 \\
2 & 0.617 & -0.112 & 29.632 & 0.000 \\
3 & 0.462 & -0.009 & 36.181 & 0.000 \\
4 & 0.338 & -0.019 & 39.847 & 0.000 \\
5 & 0.207 & -0.109 & 41.298 & 0.000 \\
6 & 0.117 & 0.023 & 41.785 & 0.000 \\
7 & 0.038 & -0.061 & 41.839 & 0.000 \\
8 & -0.024 & -0.026 & 41.862 & 0.000 \\
9 & -0.064 & 0.000 & 42.037 & 0.000
\end{tabular}

Source: Author's calculation

The above analysis is also confirmed by the Ljung-Box Q-statistics in Table 2 above. The Ljung-Box Q-statistics is associated with the ACF coefficients of the raw stock market returns and, this rejects the null hypothesis of no autocorrelation up to one-third of the years (Gujarati, 2004). This may be seen as evidence for the presence of ARCH effect or volatility clustering, which can be interpreted as a sign of long-range dependence in Nigeria's stock market returns during the sample period. This reveals that stock returns are not normally distributed (Mandelbrot, 1963 and Fama, 1965). It also shows that stock market returns exhibit leptokurtosis, skewness and volatility clustering which are the popular features of financial time series (Rydberg, 2000).

Given the above features that characterize Nigeria's stock market returns (SMI), Ordinary Least Square (OLS) model becomes inadequate to analyze data that exhibit variances that change through time (Rachev et al., 2007). On this basis, Engle (1982) developed a new method-the Autoregressive Conditional Heteroskedasticity (ARCH) model. This was later modified by Bollerslev (1986). The modified version becomes an extension to the ARCH ( $p$ ) model known as Generalized Autoregressive Conditional Heteroskedasticity (GARCH) model. This model is designed to account for a time-varying variance that usually is associated with high frequency financial and economic data. Hence, to capture the effect of the time-varying variance of Nigeria's stock returns, this study adopts the standard GARCH (1,1)-Mean model (Bollerslev, 1987 and Engle, 1993).

Following the above discussions, the GARCH model as prescribed by Engle, Lilien and Robins (1987) is specified as follows:

$$
\begin{aligned}
& \mathrm{K}=1 \quad \mathrm{~K}=1 \quad \mathrm{~K}=1 \quad \mathrm{~K}=1 \quad \mathrm{~K}=1 \\
& \text { DLNSMI }_{t}=\theta_{0}+\sum \Theta_{1} \text { DLNINFR }_{t}+\sum \Theta_{2} \text { DLNGEXP }_{t}+\sum \theta_{3} \text { DLNFEXR }_{t}+\sum \theta_{4} D L N I M O_{t}+\sum \theta_{5} D_{L N B M S_{t}} \\
& \mathrm{i}=1 \quad \mathrm{i}=1 \quad \mathrm{i}=1 \quad \mathrm{i}=1 \quad \mathrm{i}=1 \\
& \mathrm{~K}=1 \\
& +\sum \theta_{6} D L N I N R_{t}+\phi_{1} \sqrt{h}+\mu_{t} \\
& \mathrm{i}=1 \\
& \mu_{t} / \Omega_{\mathrm{t}-1} \sim \mathrm{N}\left(0, \mathrm{~h}^{2}{ }_{\mathrm{t}}\right) \\
& h^{2}{ }_{t}=\theta_{o}+\lambda_{1} \mu_{t-1}^{2}+\phi_{1} h_{t-1}^{2}
\end{aligned}
$$

Where $L N$ is the natural logarithm, $\theta_{0}$ is the intercepts of the regression and is the constant terms representing risk free rate, $\theta_{1}, \theta_{2}, \theta_{3}, \theta_{4} ; \theta_{5}, \theta_{6}, \theta_{7}$ are the coefficient of variables, $\mathrm{D}$ denotes first differences of the variables and $\mu_{t}$ is the residual errors of the regression.

$\theta_{j}, \lambda_{1}$, and $\phi_{l}$ are coefficients to be estimated $(\mathrm{j}=0,1,2), h_{t}^{2}$ is the conditional variance which is dependent on lagged values of squared errors and lagged values of the conditional variance, $\Omega_{\mathrm{t}-1}$ is the set of all information available at time $_{\mathrm{t}-1} \cdot \lambda_{l}$ and $\phi_{1}$ are the $\mathrm{ARCH}$ and GARCH coefficients, respectively, and all other terms assume the usual 
interpretations of the GARCH model. Equation (1) is the conditional mean return expression, while Equation (2) gives the distribution of the error term, conditional upon available information. Equation (3) gives an expression for the volatility of returns. It is a function of three terms. The first is the mean of yesterday's forecast, $\theta_{o}$, the second is the lag of the squared residual obtained from the mean equation $\mu_{t-1}^{2}$ or the ARCH term. The ARCH terms represent the news (information) about volatility of previous period that has an impact on the current volatility. The third term is the GARCH term, $h t-1$, measuring the impact of last period's forecast variance. $\lambda 1$ and $\phi 1$ help in confirming the presence of ARCH and GARCH effects, as in equation(3).

The size of the parameters $\lambda 1$ and $\phi 1$ determines the short-run dynamics of the volatility of the data, and the sum of the estimated $\lambda$ land $\phi 1$ reveals the persistence of volatility to a particular shock. A large positive value of $\lambda 1$ shows that strong volatility clustering is present in the time series of in question. A large value of $\phi 1$ reveals that the impact of the shocks to the conditional variance lasts for a long time before dying out, so volatility is persistent (Alexander, 2007). The $\operatorname{GARCH}(q, p)$ model is covariance stationary if and only if $\lambda 1+\phi 1<1$ (Nelson, 1990) while if $=\lambda 1+$ $\phi 1>1$, this implies that the GARCH model is non-stationary; the volatility will eventually explode to infinity as time goes to infinity and, if $\lambda_{1}+\phi_{1}=1$, this shows a case of a restricted version of the standard GARCH model which is well known in the literature as the Integrated Generalized Autoregressive Conditional Heteroskedasticity or IGARCH model (Alexander, 2007; and Rachev et al. 2007).

\section{Result and Discussion}

Table 3 below presents the GARCH-Mean, Variance equations and of the $\operatorname{GARCH}(1,1)$ model using the maximum likelihood method and, different diagnostic fits of the model. The mean equation clearly shows that INFR, GEXP, $I M O$ and MRR influenced the stock mean returns, while EXRATE and BMS have no form of influence on stock mean returns.

Table 3. Estimates of the GARCH(1,1)-M Model

\begin{tabular}{|c|c|c|c|c|}
\hline \multicolumn{5}{|c|}{ Panel A: Mean Equation } \\
\hline Variable & Coefficient & Std. Error & z-Statistic & Prob. \\
\hline$\Theta$ & 0.335862 & 0.220974 & 1.519913 & 0.1285 \\
\hline DLINFR & 0.539515 & 0.165552 & 3.258896 & 0.0011 \\
\hline DLGEXP & 0.371696 & 0.126481 & 2.938749 & 0.0033 \\
\hline DLBMS & -0.094192 & 0.175502 & -0.536698 & 0.5915 \\
\hline DLEXRATE & 0.018489 & 0.105591 & 0.175102 & 0.8610 \\
\hline DLIMO & -0.554495 & 0.322566 & -1.719012 & 0.0856 \\
\hline DLMRR & -0.669377 & 0.162193 & -4.127043 & 0.0000 \\
\hline$\sqrt{h}$ & -1.209707 & 0.204411 & -5.918010 & 0.0000 \\
\hline \multicolumn{5}{|c|}{ Panel B: Variance Equation } \\
\hline$\Theta$ & 0.026059 & 0.026059 & 2.948191 & 0.0032 \\
\hline$\Lambda(-1)^{\wedge} 2$ & -0.448990 & -0.448990 & -1.791573 & 0.0732 \\
\hline$\phi(-1)$ & 0.969934 & 0.969934 & 2.471417 & 0.0135 \\
\hline \multicolumn{5}{|c|}{$\Lambda+\phi=0.520944<1$} \\
\hline \multicolumn{5}{|c|}{ Panel C: Diagnostic Fitting } \\
\hline \multicolumn{5}{|c|}{ Q-test $(1)=0.2342(0.628)$} \\
\hline \multicolumn{5}{|c|}{ Jarque-Bera $=2.192(0.3342)$} \\
\hline \multicolumn{5}{|c|}{ Q-test $(8)=0.584(0.584)$} \\
\hline \multicolumn{5}{|c|}{ Kurtosis $=1.4586$} \\
\hline \multicolumn{5}{|c|}{$Q^{2}$-test $(1)=0.1933(0.660)$} \\
\hline \multicolumn{5}{|c|}{ Skewness $=0.0612$} \\
\hline \multicolumn{5}{|c|}{$Q^{2}$-test $(8)=13.262(0.103)$} \\
\hline \multicolumn{5}{|c|}{ ARCH-LM Test $(1)=0.1711(0.6791)$} \\
\hline ARCH-LM T & )$=10.41659(0.317$ & & & \\
\hline
\end{tabular}

Source: Authors' Computation 
In panel A of mean equation, it is clearly seen that Inflation rate has a positive or increasing-mean effect. This is consistent with the findings of Choudhry (2001), Maysami et al. (2004), Mohammed et al. (2007), Ibrahim and Aziz (2003). This suggests that increasing inflation in the economy pushes the prices of stocks and thus, market returns upward, especially when returns to stocks are expected to rise. The reason for this relationship is anchored on the adequacy of hedging role of stock against inflation. This clearly shows that Nigeria's stocks can be used as a hedge against inflation, since the positive effect of inflation implies a higher expected return is required for higher inflation rate.

Minimum Rediscount Rate (MRR) has a negative or dampening-mean effect on stock-mean returns. The relationship between stock returns and Minimum rediscount rate is found to be negative. French et al. (1987), Fama and Schwert (1977) also reports that negative relationship exists between interest rate and stock returns. The period under review was characterized by the increasing debt financing requirement of the government. Therefore, interest rates were mostly governed by debt structure of government and the real interest rates were enormously high to attract short-term capital. Hence, both foreign and domestic investors didn't see investment in Nigeria's stock Exchange as an alternative investment opportunity. As the interest rate rises, investors tend to invest less in stocks causing stock prices to plummet. When interest rate is high, rational investors tend to invest in less risky asset (money market) with high returns. Hence, the money and capital markets in the Nigerian economy are alternative investment opportunities in the long run. This affected the performance of the Nigerian Stock Exchange under the reviewed period.

Government Expenditure (GEXP) is positively related to stock returns. The increasing Government Expenditure through fiscal deficits necessitated the rise in the level of money supply in the economy and, this generally affects all prices in the economy, stock prices not exclusive. This result is not surprising, given the fiscal irresponsibility experienced over the years.

Index of Manufacturing Output (IMO) is significant as expected, but with a wrong sign. This relationship is contrary with what is expected. The increase in cash flow experienced by firms in Nigeria was not strong enough to attract potential investors. The reason being that the ever-increasing cost of production mitigates firms performance. That is, IMO dynamics were mostly driven by change in capacity utilization ratios and, also the failure to paying dividend as when due. These made investors to have a shift in their portfolio. Hence, these factors explain the reason for wrong apriori expectation of the stock returns.

Exchange rate (EXRATE) is positively related to stock returns, but not significantly. This is in line with Geske and Roll (1983), Malliaropulos (1998) and, Alshogeathri, (2011) that found a positive influence. This is attributed to the depreciation of naira which is expected to increase stock returns through increase in competition. However, due to the structure of the economy, Nigeria being an importing nation, the cost of imports enclosed the gain that would have accrued to firms operating in the stock market. This might be an evidence for the insignificant effects of the exchange rate on stock returns in Nigerian stock market.

Broad Money supply (BMS) has a negative relationship with stock returns, though insignificant. This supports the view of Udegbunam and Oaikhenan (2002), Alshogeathri (2011) and, Osamwonyi and Evbayiro-Osagie (2012). This is not uncommon, since the present theoretical and empirical studies showed no consensus relationship between money supply and the stock market returns. The insignificance of the result is also in line with Chancharat, Valadkhani, and Havie (2007) that showed that money supply has no impact on stock returns. However, this result is contrary to Mukherjee and Naka (1995), Maysami and Koh (2000) and, Wongbangpo and Sharma (2002). However, these findings could be assumed as an indication that the money supply's relationship with stock returns is an empirical issue (Alshogeathri, 2011).

Finally, the significant impact of the estimated coefficient, $\phi_{l}$ of the time varying conditional variance $\sqrt{h}$ indicates that volatility has a negative impact on Nigeria's stock market returns in the period under review. That is, there seems to be evidence of a GARCH-in-mean effect in the model. However, the evidence on the volatility of the conditional variance of $\mu_{t}$ (i.e. $h_{\mathrm{t}}^{2}$ ) is rather mixed. The estimate of $h_{\mathrm{t}}^{2}$ is positively significant, but the estimate of $\sqrt{h}$ is negatively significant. This could be attributed to the fact that, as shocks to the conditional variance take a long time to die out, that is, as volatility persistent investors no longer believe in the efficacy of the market hence, they look for an alternative investment opportunities (see Panel B).

The variance equation in panel B shows that, the $\operatorname{ARCH}(\Lambda)$ and $\operatorname{GARCH}(\phi)$ coefficients are found to be significant. Though the estimate of ARCH appeared with a negative sign. However, this provides evidence of ARCH and GARCH effect on volatility of stock returns in Nigeria. This shows that there is volatility clustering in Nigerian stock market. 
The negative sign of ARCH observed is in contrast with Engle (1982) and, Bollerslev's (1986), whose emphases are on a non-negative estimate of the ARCH. However, Nelson and Cao (1992) and, He and Terasvirta (1999) revealed that Bollerslev's (1986) non-negativity conditions are too restrictive, as such negative estimates may be obtained. Also, Alshogeathri (2011) observed that in the GARCH model, the sign of the shock is irrelevant, but the magnitude of the positive or negative shocks is the only factor that matters for conditional volatility. That good news corresponds to negative shocks $\left(\mu_{\mathrm{t}-1}^{2}<0\right)$ since it leads to a fall in conditional volatility, while bad news corresponds to positive shocks $\left(\mu_{t-1}^{2}>0\right)$ since it brings about increase in conditional volatility.

The sum of the ARCH and GARCH coefficients is less than one $(\Lambda+\phi=0.520944<1)$, which reveals that the unconditional variance is stationary. Since the sum of $\Lambda_{1}+\phi_{1}$ is averagely close to one, the time-varying volatility of the Nigeria's stock market returns is moderately persistent. In other words, a shock to the Nigeria's stock market volatility will not last too long. That is, there is a mean reverting variance process. The $\Lambda_{1}$ is lower than $\phi_{1}$, which implies that the volatility of the stock market is affected by past volatility $\left(\Lambda_{1}\right)$ more than the economic news from the previous period $\left(\phi_{1}\right)$. Also, the large GARCH coefficient $\left(\phi_{1}=0.969934\right)$ indicates that shocks to the conditional variance take a long time to die out, so volatility is persistent.

In terms of the adequacy of the estimated GARCH $(1,1)$ model, panel $\mathrm{C}$ contains the diagnostic tests of the residuals generated from GARCH $(1,1)$ model. The Q-test and $\mathrm{Q}^{2}$-test show no serial correlation of the standardized residuals obtained from the GARCH $(1,1)$ model up to order 8 . This is evidence that the mean and variance equation for Nigeria's stock returns is correctly specified. The ARCH-LM test results also confirmed the above results. The Jarque-Bera statistic also rejects the hypothesis of non-normality with a kurtosis statistic of 2.016. These findings show support for the adequacy of the standard $\operatorname{GARCH}(1,1)$ model as a benchmark to examine the dynamic behavior of the Nigeria's stock market with the volatility of the macroeconomic variables in the system.

\section{Summary and Conclusions}

This study examines the impact of domestic macroeconomic variables on stock returns with a time-varying parameter model of GARCH $(1,1)$ specification. This method of analysis captures the changing dynamics between macroeconomic factors and Nigeria's stock market returns. It captures GARCH-Mean and Variance equations. The study employed secondary data between1985-2009. The study differs from other studies in Nigeria, by taking into account the time-varying financial series and, also considers the effect of government expenditure on stock returns in Nigeria.

Of the six macroeconomic variables that were selected for analysis on basis of GARCH-mean equation, inflation, government expenditure, index of manufacturing output and, interest rate, exert strong significant influence on stock returns while money supply and foreign exchange rate exert no significant influence on stock returns in Nigeria. The significant impact of the estimated coefficient, $\phi_{l}$ of the time varying conditional variance $\sqrt{h}$ indicates that volatility exert a negative impact on Nigeria's stock market returns in the period under review. That is, there seems to be evidence of a GARCH-in-mean effect in the model. However, the evidence on the volatility of the conditional variance of $\mu_{t}\left(\right.$ i.e. $\left.h^{2}\right)$ is rather mixed.

On the GARCH-variance equation, Volatility of Nigeria's stock market returns was affected by past volatility more than the economic news from the previous period $\left(\phi_{1}\right)$. The time-varying volatility of the Nigeria's stock market returns is moderately persistent. In other words, a shock to the Nigeria's stock market volatility will last moderately long. .Also, the large GARCH coefficient $\left(\phi_{1}=0.969934\right)$ indicates that shocks to the conditional variance take a long time to die out, so volatility is persistent.

There is no doubt that stock market is a very risky channel of investment. However, investors and policy makers might predict the dynamics of the stock market through domestic fluctuation of macroeconomic variables. That is, policy makers and investors of the Nigeria stock market should take note of the systematic risks revealed by inflation, government expenditure, index of manufacturing and interest rates when structuring portfolios and diversification strategies. Also, financial regulators need to take these macroeconomic variables into account when formulating economic and financial policies.

Given that a set of macroeconomic variables were used in this study; the macroeconomic variable set employed is not exhaustive. Some other macroeconomic variables would provide more information about the stock returns volatility. This study also suggests some future studies that incorporate other macroeconomic variables other than the ones used in this study to enhance the understanding about the dynamics of the stock market returns in less developed countries, Nigeria in particular. 


\section{References}

Ajayi, R. A., \& Mougoue, M. (1996). On the Dynamic Relation between Stock Prices and Exchange Rates. The Journal of Financial Research, 19, 193-207.

Alexander, C. (2007). Market Models: A Guide to Financial Data Analysis. John Wiley and Sons Ltd, New York.

Alile, H.I (1984). The Nigerian Stock Exchange: Historical Perspective, Operations and Contributions to Economic Development. Central Bank of Nigeria Bullion, (Silver Jubilee Edition), 2, 65-69.

Alshogeathri, M.A. M. (2011). Macroeconomic Determinants of the Stock Market Movements: Empirical Evidence From the Saudi Stock Market. An Abstract of a Dissertation, University Manhattan, Kansas State.

Amadi, S.N., Onyema, J.I., \& Odubo, T.D. (2002). Macroeconomic Variables and Stock Prices. A Multivariate Analysis. Africa Journal of Development Studies, 2(1), 159-164.

Anokye, M. A., \& Tweneboah, G. (2008). Macroeconomic Factors and Stock Market Movement: Evidence from Ghana. MPRA Paper No.11256, Munich, Munich Personal RePEc Archives.

Asaolu, T.O., \& Ogunmuyiwa, M.S. (2011). An Econometric Analysis of the Impact of Macroecomomic Variables on Stock Market Movement in Nigeria. Asian Journal of Business Management, 3(1), 72-78.

Barrows, W. C., \& Naka, A. (1994). Use of Macroeconomic Variables to Evaluate Selected Hospitality Stock Returns in the U.S.. International Journal of Hospitality Management, 13(2), 119-128. http://dx.doi.org/10.1016/0278-4319(94)90033-7

Barsky, R. (1989). Why don't the Prices of Stocks and Bonds Move Together? American Economic Review, 79 , 1132-1145.

Beenstock, M., \& Chan, K.F. (1988). Economic Forces in London Stock Market. Oxford Bulletin of Economics and Statistics, 50, 22-39.

Bilson, C. M., Brailsford, T. J., \& Hooper, V. J. (2001). Selecting Macroeconomic Variables as Explanatory Factors of Emerging Stock Market Returns. Pacific-Basin Finance Journal, 9(4), 401-426. http://dx.doi.org/10.1016/S0927-538X(01)00020-8

Bollerslev, T, Chou, R. Y., \& Kroner, K. F. (1992). ARCH Modeling in Finance. Journal of Econometrics, 52, 5-59. http://dx.doi.org/10.1016/0304-4076(92)90064-X

Bollerslev, T. (1986). Generalized Autoregressive Conditional Heteroskedasticity. Journal of Econometrics, 31, 307-327. http://dx.doi.org/10.1016/0304-4076(86)90063-1

Bollerslev, T. (1987). A Conditionally Heteroskedasticity Time Series Model for Speculative Prices and Rates of Return. Review of Economics and Statistics, 69, 542-547. http://dx.doi.org/10.2307/1925546

Brown, J. Stephen, \& Otsuki, T. (1990). Macroeconomic Factors and the Japanese Equity Markets: The CAPMD Project. In E.J. Elton and M. Gruber (Eds.), Japanese Capital Markets (pp.175-192). New York: Harper and Row.

Burmeister, Edwin, \& Wall, D. K. (1986). The Arbitrage Pricing Theory and Macroeconomic Factor Measures. The Financial Review, 21, 1-20. http://dx.doi.org/10.1111/j.1540-6288.1986.tb01103.x

Buyuksalvarci, A. (2010). The Effects of Macroeconomics Variables on Stock Returns: Evidence from Turkey. European Journal of Social Sciences, 14(3), 404-416.

Central Bank of Nigeria Statistical Bulletin, Abuja.

Chancharat, S., Valadkhani, A., \& Harvie, C. (2007). The Influence of International Stock Markets and Macroeconomic Variables on the Thai Stock Market. Faculty of Commerce - Papers (Archive), University of Wollongong.

Chandra P. (2004). Investment Analysis and Portfolio Management. New Delhi: McGraw-Hill.

Chen, N. (1991). Financial investment opportunities and the macroeconomy. Journal of Finance, (46), 529-554. http://dx.doi.org/10.1111/j.1540-6261.1991.tb02673.x

Chen, N. F. (1991). Financial Investment Opportunities and the Macroeconomy. Journal of Finance, 46(1), 5, 29-583. 
Chen, N., Roll, R., \& Ross, S. (1986). Economic forces and the stock market. Journal of Business, 59(3), 383-403. http://dx.doi.org/10.1086/296344

Chen, N.F. (1983). Some Empirical Tests of the Theory of Arbitrage Pricing. Journal of Finance, 38, 1393-1414. http://dx.doi.org/10.1111/j.1540-6261.1983.tb03831.x

Cheung, Y.W., \& Ng, L.K. (1998). International Evidence on the Stock Market and Aggregate Economic Activity. Journal of Empirical Finance, 5, 281-296. http://dx.doi.org/10.1016/S0927-5398(97)00025-X

Choudhry, T. (2000). Inflation and Rates of Return on stocks: Evidence from high inflation countries. Journal of International Financial Markets, Institutions, and Money, 11, 75-96. http://dx.doi.org/10.1016/S1042-4431(00)00037-8

Clare, A.D., \& Thomas, S.H. (1994). Macroeconomic Factors, The APT and UK Stock Market. Journal of Business Finance and Accounting, 21, 309-330. http://dx.doi.org/10.1111/j.1468-5957.1994.tb00322.x

Diacogiannis, G.P. (1986). Arbitrate Pricing Model: A critical Examination of its Empirical Applicability for the London Stock Exchange. Journal of Business, Finance and Accounting, 113(5), 489-504. http://dx.doi.org/10.1111/j.1468-5957.1986.tb00513.x

Engle, R. F. (1982). Autoregressive Conditional Heteroskedasticity with Estimates of the Variance of UK Inflation. Econometrica, 50, 987-1007. http://dx.doi.org/10.2307/1912773

Engle, R. F. (1993). Statistical Models for Financial Volatility. Financial Analysts Journal, 49, $72-78$. http://dx.doi.org/10.2469/faj.v49.n1.72

Engle, R. F., \& Ng, V. K. (1993). Measuring and Testing the Impact of News on Volatility. The Journal of Finance, 48(5), 1749-1778. http://dx.doi.org/10.1111/j.1540-6261.1993.tb05127.x

Erdogan, E., \& Ozlale, U. (2005). Effects of Macroeconomic Dynamics on Stock Returns: the Case of the Turkish Stock Market. Journal of Economic Cooperation, 26, 69-90.

Fama, E. F. (1965). The Behavior of Stock-Market Prices. Journal of Business, 38, 34-105. http://dx.doi.org/10.1086/294743

Fama, E. F. (1981). Stock Returns, Real Activity, Inflation, and Money. The American Economic Review, 71(4), 545-565.

Fama, E. F., \& Schwert, G. W. (1977). Asset Returns and Inflation. Journal of Financial Economics, 5(2), 115-146, Elsevier. http://dx.doi.org/10.1016/0304-405X(77)90014-9

Fifield, S. G. M., Power, D. M., \& Sinclair, C. D. (2002). Macroeconomic Factors and Share Returns: An Analysis using Emerging Market Data. International Journal of Finance and Economics, 33(1), 51-62. http://dx.doi.org/10.1002/ijfe.173

French, K.R., Schwert, G.W., \& Stambaugh, R.E. (1987). Expected Stock Return and Volatility. Journal of Financial Economics, 19, 3-29. http://dx.doi.org/10.1016/0304-405X(87)90026-2

Gan, C, Lee, M., Yong, H. H. A., \& Zhang, J. (2006). Macroeconomic Variables and Stock Market Interactions: New Zealand Evidence. Investment Management and Financial Innovation, 3(4), 89-101.

Gazi, M. H., \& Hisham, A. (2010). Can Macroeconomic Factors Explain Equity Returns in the Long Run? The Case of Jordan. Draft 4-15/05/2010, School of Economics and Finance, University of Western Sydney, Australia.

Geske R., \& Roll, R. (1983). The Fiscal and Monetary Linkage between Stock Returns and Inflation. Journal of Finance, 38, 7-33. http://dx.doi.org/10.1111/j.1540-6261.1983.tb03623.x

Gjerde, O., \& Saettem, F. (1999). Causal Relations among Stock Returns and Macroeconomic Variables in a Small Open Economy. Journal of International Financial Markets, Institutions and Money, 9, 61-74. http://dx.doi.org/10.1016/S1042-4431(98)00036-5

Gujarati, D.N. (2004). Basic econometrics ( $4^{\text {th }}$ ed.). Tata McGraw-Hill, New Delhi.

Hamao, Y. (1988). An Empirical Investigation of the Arbitrage Pricing Theory. Japan and the World Economy, 1, 45-61. http://dx.doi.org/10.1016/0922-1425(88)90005-9

Hashemzadeh, N., \& Taylor, P. (1988). Stock Prices, Money Supply, and Interest Rate: The Question of Causality. Applied Economics, 20, 1603-1611. http://dx.doi.org/10.1080/00036848800000091 
He, C., \& Terasvirta, T. (1999). Properties of the Autocorrelation Function of Squared Observations for Second-Order GARCH Processes under Two Sets of Parameter Constraints. Journal of Time Series Analysis, 20, 23-30. http://dx.doi.org/10.1111/1467-9892.00123

Ibrahim, H.M., \& Aziz, H. (2003). Macroeconomic Variables and the Malaysian Equity Market: A View Through Rolling Subsamples. Journal of Economic Studies, 3(1), 6-27. http://dx.doi.org/10.1108/01443580310455241

Ibrahim, M. H. (1999). Macroeconomic Variables and Stock Prices in Malaysia: An Empirical Analysis. Asian Economic Journal, 13(2), 219-231. http://dx.doi.org/10.1111/1467-8381.00082

Islam S.M.N., \& Watanapalachaikul, S. (2003). Time Series Financial Econometrics of the Thai Stock Market: A Multivariate Error Correction and Valuation Model. CSES Annual Report.

Kandir, S.Y. (2008). Macroeconomic Variables, Firm Characteristics and Stock Returns: Evidence from Turkey. International Research Journal of Finance and Economics Issue, 16, 35-45.

Kaul, G. (1987). Stock Returns and Inflation: The role of the Monetary sector. Journal of Financial Economics, 18, 253-276. http://dx.doi.org/10.1016/0304-405X(87)90041-9

Kirchler, M., \& Huber, J. (2007). Fat Tails and Volatility Clustering in Experimental Asset Markets. Journal of Economic Dynamics and Control, 31, 1844-1874. http://dx.doi.org/10.1016/j.jedc.2007.01.009

Kwon, C.S., \& Shin, T.S. (1999). Co-intergation and Causality between Macroeconomic Indicators and Stock Exchange Prices. Global Financial Journal, 10(1), 71-81. http://dx.doi.org/10.1016/S1044-0283(99)00006-X

Kyereboah-Coleman, A., \& Agyire-Tettey, K.F. (2008, September). Impact of macroeconomic indicators on stock market performance: The case of the Ghana stock exchange. Journal of Risk Finance, 5(2).

Lee, B. (1992). Causal Relations among Stock Returns, Interest Rate, Real Activity and Inflation. Journal of Finance, 1591-1603. http://dx.doi.org/10.1111/j.1540-6261.1992.tb04673.x

Lee, T. H. (1994). Spread and Volatility in Spot and Forward Exchange Rates. Journal of International Money and Finance, 13, 375-383. http://dx.doi.org/10.1016/0261-5606(94)90034-5

Maku O. E., \& Attanda, A. A. (2009). Does Macroeconomic Indicators Exert shock on the Nigerian Capital Market? Retrieved from http://mpra.ub.uni-muenchen.de/17917/

Malliaropulos, D. (1988). International Stock Relations Differentials and Real Exchange Rates. Journal of International Money and Finance, 17, 493-511. http://dx.doi.org/10.1016/S0261-5606(98)00013-8

Mandelbrot, B. (1963). The Variation of Certain Speculative Prices. The Journal of Business of the University of Chicago, 36, 394-419.

Mangani, R. (2009). Macroeconomic Effects on Individual JSE Stock: A GARCH Representation. Investment Analysts Journal, (69), 47-57.

Maysami, R. C, Howe, L. C., \& Hamzah, M. A. (2004). Relationship between Macroeconomic Variables and Stock Market Indices: Cointegration Evidence from Stock Exchange of Singapore's All-S Sector Indices. Journal of Pengurusan, 24, 47-77.

Maysami, R.C., \& Koh, T.S. (2000). A Vector Error Correction Model of the Singapore Stock Market. International Review of Economics and Finance, 9, 79-96. http://dx.doi.org/10.1016/S1059-0560(99)00042-8

Mohammed, A. M. T., Wisam, R., Hassama, A., \& Bin Amin, F. M. (2007). Effects of Macroeconomic Variables on Stock Prices In Malaysia: An Approach Of Error Correction Model. International Islamic University Malaysia, Jalan Gombak-53100, Kuala Lumpur, Malaysia.

Mukherjee T.K., \& Naka, A. (1995). Dynamic Relations between Macroeconomic Variables and the Japanese Stock Market. An application of Vector Error Correction Model. Journal of Finance Research, 18, 223-237.

Nelson, D. B. (1990). Stationarity and Persistence in the GARCH (1,1) Model. Econometric Theory, 6, 318-334. http://dx.doi.org/10.1017/S0266466600005296

Nelson, D. B. (1991). Conditional Heteroskedasticity in Asset Returns: A New Approach. Econometrica, 59, 347-370. http://dx.doi.org/10.2307/2938260

Nelson, D. B., \& Cao, C. Q. (1992). Inequality Constraints in the Univariate GARCH Model. Journal of Business and Economic Statistics, 10, 229-235.

Nigeria Security and Exchange Commission Quarterly, Vol. 1, January-March, 2008. 
Osamwonyi, I.O., \& Evbayiro-Osagie, E. I. (2012). The Relationship between Macroeconomic Variables and Stock Market Index in Nigeria. Journal of Economics, 3(1), 55-63

Osamwonyi, I.O. (2003). Forecasting as a Tool for Securities Analysis, A Paper Presented at a Three-day Workshop on Introduction to Securities Analysis. Organized by Securities and Exchange Commission, Lagos, August 17th.

Pearce, D., \& Roley, V.V. (1983). The Reaction of the Stock Prices to Unanticipated Changes in Money: a Note. The Journal of Finance, 38, 1323-1333. http://dx.doi.org/10.1111/j.1540-6261.1983.tb02303.x

Poon, S., \& Taylor, S.J. (1991). Macroeconomic Factors and the UK Stock Market. Journal of Business and Accounting, 18(5), 619-636. http://dx.doi.org/10.1111/j.1468-5957.1991.tb00229.x

Priestly, R. (1996). Arbitrate Pricing Theory, Macroeconomic and Financial Factors and Expectations Generating Processes. Journal of Banking and Finance, 20, 869-890. http://dx.doi.org/10.1016/0378-4266(95)00035-6

Quadir, M. M. (2012). The Effect of Macroeconomic Variables on Stock Returns on Dhaka Stock Exchange. International Journal of Economics and Financial Issues, 2(4), 480-487.

Rachev, S., Mittnik, S., Fabozzi, F., Focardi, S., \& Jasic, T. (2007). Financial Econometrics: From Basics to Advanced Modeling Techniques. Frank J. Fabozzi Series, John Wiley \& Sons Inc.

Robert, D.G. (2008). Effect of Macroeconomic Variables on Stock Market Returns for Four Emerging Economies: Brazil, Russia, India and China. International Business, Economics Research Journal, 7(3).

Ross, S.A. (1976). The Arbitrage Pricing Theory of Capital Assets Pricing. Journal of Economic Theory, 13, 341-360. http://dx.doi.org/10.1016/0022-0531(76)90046-6

Rydberg, T. H. (2000). Realistic Statistical Modeling of Financial Data. International Statistical Review, 68(3), 233-258. http://dx.doi.org/10.1111/j.1751-5823.2000.tb00329.x

Sadorsky, P. (1999). Oil Price Shocks and Stock Market Activity. Energy Economics, 21(5), 449-469. http://dx.doi.org/10.1016/S0140-9883(99)00020-1

Serletis, A. (1993). Money and Stock Prices in the United States. Applied Financial Economics, 3, 51-54. http://dx.doi.org/10.1080/758527816

Sharpe, W. F. (1964). Capital Asset Prices: A Theory of Market Equilibrium under Conditions of Risk. Journal of Finance, 19, 425-442.

Shiller, R.J., \&, Beltratti, A.E. (1992). Stock Prices and Bond Yields: Can the Comovements be Explained in Terms of Present Value Model? Journal of Monetary Economics, 30, 25-46. http://dx.doi.org/10.1016/0304-3932(92)90042-Z

Soyode, A. (1993). Nigerian Capital Markey and Macroeconomic Variables: An Empirical Analysis. Nigerian Journal of Monetary Economics, 3.

Tunah Halil. (2010). The Analysis of Relationships between Macroeconomic Factors and Stock Returns: Evidence from Turkey Using VAR Model. International Research Journal of Finance and Economics.

Tursoy, T., Gunsel, N., \& Rjoub, H. (2008). Macroeconomic Factors, the APT and the Istanbul Stock Market. International Research Journal of finance and Economics, (22).

Udegbunam, R.I., \& Oaikhenan, H.E. (2002). Fiscal deficits, money stock Growth and the Behavior of Stock Prices in Nigeria: An Empirical Investigation. Journal of Financial Management and Analysis, 4, 10-27.

Wongbangpo, P., \& Sharma, S.C. (2002). Stock Market and Macroeconomic Fundamental Dynamic Interactions: ASEAN-5 Countries. Journal of Asian Economics, 13, 27-51. http://dx.doi.org/10.1016/S1049-0078(01)00111-7 